\title{
STRUCTURAL MATERIALS FOR BREEDER REACTOR CORES AND COOLANT CIRCUITS
}

\section{R. Diercks*}

Materials Science and Technology Division

Argonne National Laboratory

Argonne, Illinois 60439

February 1984

DOE/MBN- -4009194

DE84 009194
The submitted manuscript has been authored by a contractor of the $U S$ Government under contract No W-31 109-ENG-38 Accordingly, the U.S Government retains a nonexclusive, royalty-free license to publish or reproduce the published form of this contribution, or allow others to do so, for U S. Government purposes

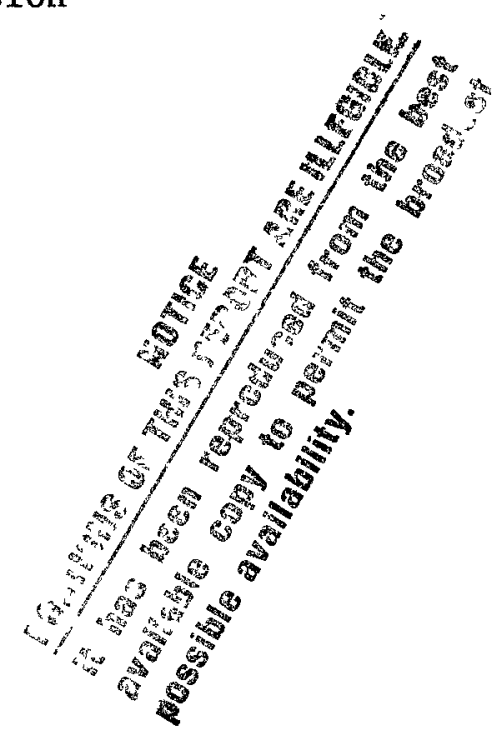

\section{DISCLAIMER}

This report was prepared as an account of work sponsored by an agency of the United States Government. Neither the United States Government nor any agency thereof, nor any of their employees, makes any warranty, express or implied, or assumes any legal liability or responsibility for the accuracy, completeness, or usefulness of any information, apparatus, product, or process disclosed, or represents that its use would not infringe privately owned rights. Reference herein to any specific commercial product, process, or service by trade name, trademark, manufacturer, or otherwise does not necessarily constitute or imply its endorsement, recommendation, or favoring by the United States Government or any agency thereof. The views and opinions of authors expressed herein do not necessarily state or reflect those of the United States Government or any agency thereof.

Invited article to the ENCYCLOPEDIA OF MATERIALS SCIENCE AND ENGINEERING, Pergamon Press.

*Author supported by the U. S. Department of Energy, Office of Fossil Energy, office of Advanced Research and Technology.

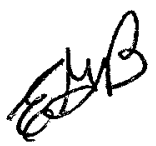




\section{DISCLAIMER}

This report was prepared as an account of work sponsored by an agency of the United States Government. Neither the United States Government nor any agency Thereof, nor any of their employees, makes any warranty, express or implied, or assumes any legal liability or responsibility for the accuracy, completeness, or usefulness of any information, apparatus, product, or process disclosed, or represents that its use would not infringe privately owned rights. Reference herein to any specific commercial product, process, or service by trade name, trademark, manufacturer, or otherwise does not necessarily constitute or imply its endorsement, recommendation, or favoring by the United States Government or any agency thereof. The views and opinions of authors expressed herein do not necessarily state or reflect those of the United States Government or any agency thereof. 


\section{DISCLAIMER}

Portions of this document may be illegible in electronic image products. Images are produced from the best available original document. 
Structural Materials for Breeder Reactor Cores and Coolant Circuits 325/01279

The structural components of principal interest in fast-breeder reacto: cores and cooling circuits include the reactor vesse1, primary and secondary piping, intermediate heat exchanger (IHX), and steam generator. Load-bearins: components inside the vessel, among these the fuel cladding and duct, are al: included. The operating conditions present in a fast-breeder nuclear reactor impose a number of requirements on the mechanical, physical, and neutronic properties of the materials used to construct these components. Because the liquid-metal fast-breeder reactor (LMFBR) is the most technologically developed of the various fast-breeder reactor concepts proposed, it is the only reactor type discussed here.

\section{Cladding and Duct Materials}

The nuclear fuel in an IMFBR is clad in thin-wall metallic tubing to make up the individual fuel elements. These fuel elements, in turn, are assembled into hexagonal arrays of up to 200 to 300 , depending upon the reactor, and enclosed in metallic ducts to comprise the basic fuel assemblies that go into the core. Both the cladding and duct materials must maintain reasonable strengths and ductilities at temperatures of up to $\sim 700^{\circ} \mathrm{C}$ and fast neutron fluences approaching $3 \times 10^{23} \mathrm{n} / \mathrm{cm}^{2}$ ( $\left.\mathrm{E}>0.1 \mathrm{MeV}\right)$. They must also have acceptably low neutron absorption cross sections and must be chemically compatible with the reactor coolant and, in the case of cladding, with the fuel. Types 304 and 316 austenitic stainless steel were the early choices for these applications in LMFBRs. However, in the fast-reactor core environment, these alloys are subject to significant irradiation-induced creep, swelling, and embrittlement (see article on Swelling in Irradiated Materials). Swelling is reduced somewhat by prior cold working, and $20 \%$ cold-worked Type 316 stainless steel cladding and duct are used in the U.S. Fast Flux Test Facility (FFTF) and had been specified for the now-cancelled Clinch River Breeder 
Reactor (CRBR). Titanium- and/or silicon-modified cold-worked Type 316 stainless steel is being considered for the cladding and duct of the Britis: Commercial Fast Reactor (CFR) and French Creys-Malville (Super Phenix' LMFBR. Ferritic steels, and precipitation-strengthened and solid-solutionstrengthened austenitic alloys with low swelling characteristics are present 1 being investigated for future cladding and duct applications.

\section{Reactor Upper Internal Structures}

The sodium coolant in an LMFBR typically emerges from different parts of the core at different temperatures. During mixing of the exiting coolant, streams having significantly different temperatures can alternately impinge on structural components located above the core, a phenomenon known as "thermal striping." This subjects these components to rapid $(\sim 1 \mathrm{~Hz})$ temperature fluctuations, and the resultant cyclic thermal stresses create a potential highcycle fatigue problem.

Types 304 and 316 stainless steel have been chosen for the affected upper internal structure in several European LMFBRs. However, in the U.S. FFTF and CRBR designs as well as in Japan's Monju Reactor, the magnitude (up to $\sim 150^{\circ} \mathrm{C}$ ) and expected number $\left(\sim 10^{9}\right)$ of the temperature fluctuations are judged to be too severe for these alloys. Therefore, the nickel-base alloy, Inconel 718 , has been specified for such components as instrument posts, outlet chimneys, and baffle plates. This alloy possesses a higher fatigue endurance limit and thermal conductivity and a lower thermal expansion coefficient than the austenitic stainless steels. However, problems with heavy-section welding, notch sensitivity, and potential overaging limit its applicability.

\section{Reactor Vessel and Coolant Circuits}

An LMFBR is cooled by one or more coolant loops, each typically consisting of two sodium-filled circuits connected through an IHX. The primarv circuit removes hed from the reactor core and the secondary circuit supplies 
heat to the steam generator. The two-circuit design isolates the steam generators and turbines from possible contamination from the reactor core. In $\therefore$ pool-type reactor, the primary circuit and IHX are located inside the reactor vessel with the core, whereas in a loop-type reactor both circuits are external to the vesse1. Maximum operating temperatures for the vessel ar coolant circuits are generally about 530 to $560^{\circ} \mathrm{C}$.

These components comprise the primary pressure boundary of the plant. and, for commercial reactors, they must be designed in accordance with the ASME Boiler and Pressure Vessel Code in the U.S. and similar design codes in most of Europe and Japan. This limits the qualified materials of construction, and Type 304 and 316 stainless steel are used almost universally for these components, although the British Prototype Fast Reactor (PFR) has made extensive use of Type 321 stainless steel. The relatively modest coolant operating pressures (typically less than $1.5 \mathrm{MPa}$ ) limit the primary stresses, but secondary "creep-fatigue" stresses associated with startups and shutdowns (particularly under abnormal conditions) and interspersed periods of steadystate operation are an important design problem.

\section{Steam Generator}

The steam generator system in an LMFBR is made of evaporator, superheater, and, in some cases, reheater stages. Numerous designs exist, but the basic evaporator/superheater configuration commonly consists of several hundred to several thousand tubes transporting water or steam enclosed in an outer she11 through which the heated secondary sodium is circulated. The tube walls thus serve as the boundary between the water or steam and the sodium, and the outer she11 provides for sodium containment. In the U.S. CRBR design, the maximum anticipated sodium inlet temperatures to the evaporators and superheater are 457 and $502^{\circ} \mathrm{C}$, respectively, and the corresponding steam out let temperatures are 330 and $485^{\circ} \mathrm{C}$. 
The ferritic $21 / 4 \mathrm{Cr}-1$ Mo steels, sometimes stabilized with $\mathrm{Nb}$ to contrat decarburization by the sodium, remain the favored alloys for steam gentrato components. They offer proven fabricability and weldability, netallurgica stability in sodium at țemperature, compatibility with the water and stea conditions encountered, and acceptability under the ASME Code. The ferrit $9 \mathrm{Cr}-1$ Mo steel possesses somewhat higher strength at operating temperatures anc: is to be used for the British CFR evaporator and superheater tubing. Tr, austenitic alloys are also being used because of their higher strength an. relative freedom from carbon transport problems in sodium, althougle their thermal conductivities are lower. The superheater and reheater tubing in the French Phenix reactor is made of Type 321 stainless steel. Several austenitic stainless steels are being used for this same tubing in Japan's Monju Reactor and Incoloy Alloy 800 tubing is being used throughout the Super Phenis steat generator system. The PFR superheater and reheater tubing was originaliy made of Type 316 stainless steel, but because of stress-corrosion cracking experienced at tube-to-tube sheet welds, this tubing is being replaced with steel tubing and thermal sleeves.

\section{Bibliography}

Bennett J W, Horton K E 1978 Materials requirements for liquid metal fast breeder reactors. Met. Trans. 9A:143-49

Brinkman C R, Katcher M 1979 (July) Materials technology for LMFBR stean generators. Metal Progress 116:54-61

Moore J 1979 International progress with liquid metal fast reactors. Nucl. Eng. Int. 24(287):37-49

Roberts J T'A 1981 Structural Materials in Nuclear Systems. Plenum, Nev York. Author

Dwight R. Diercks, Materials Science and Technology Division, Argonne Nationat Laboratory, Argonne, Illinois 60439. 